\title{
SA's drink/drug abuse future could hang on a thread
}

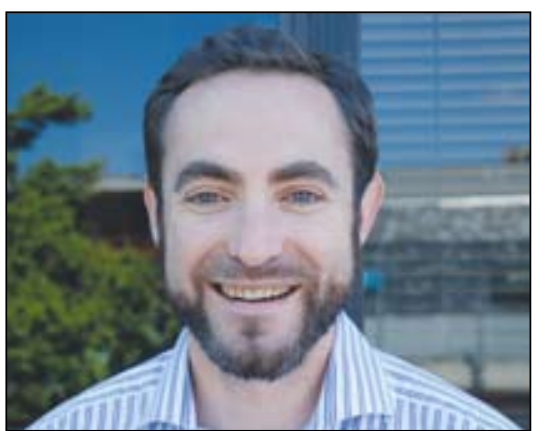

Avi Lasarow, CEO of Trimega Labs.

Picture: Chris Bateman.

A 35-year-old South African entrepreneur firmly believes he can revolutionise the local alcohol and drug testing market through gold standard hair testing technology that provides up to three months (and often more) of accurate abuse history.

What it requires, he told Izindaba, is for government policy and legislation to catch up with science and emulate other countries where his technology is widely used, enhancing judicial rulings across a host of fields. Not only could drunk or drugtaking drivers (the latter for whom no legally enforceable test exists locally) be accurately and quickly tested, but drug abusers in rehabilitation, parents or guardians with alcohol and drug dependencies and prospective adoptive parents could also be checked for historical abuse.

Using a $381 \mathrm{~mm}$ (half inch) length of hair, the analysis evaluates the number of drug metabolites imbedded inside the hair shaft (via sweat) - with every $381 \mathrm{~mm}$ of hair providing a 30-day history of drug or alcohol usage. Body hair is equally effective, making a total (and very close) body shave necessary to avoid detection. Shampooing or rigorous hair washing has little or no effect on results. Evidential snapshots from blood and liver function tests frame only a few days at best.

\section{Legal fraternity latch on}

Already lawyers in the United Kingdom and Germany are using Gauteng-born Avi Lasarow's technology to shore up their cases in custody battles, social welfare matters and drunk and drug-driving trials, while its application in the long-term monitoring of addicts to see if they have stayed 'clean' has proved invaluable. Adoption testing - where prospective parents are tested as part of their suitability criteria - is also catching on fast, while German authorities are using it as part of their criteria for motorists who re-apply for (suspended) drivers' licences. There are currently an estimated 20000 hair alcohol and drug tests requested annually in UK child custody cases.

Already lawyers in the United Kingdom and Germany are using Gauteng-born Avi Lasarow's technology to shore up their cases in custody battles, social welfare matters and drunk and drug-driving trials, while its application in the long-term monitoring of addicts to see if they have stayed 'clean' has proved invaluable.

Two areas of application in South Africa excite Lasarow, whose company Trimega Labs can also check for the presence of the five most popular recreational drugs in a person's hair. The first is antiretrovirals (ARV) compliance (and abuse), and the second is fetal alcohol syndrome (FAS). South Africa has the world's greatest prevalence of both AIDS and FAS. A single test of a person living with AIDS can show if they have remained compliant over the past year (there are increasing reports of ARV users selling their drugs to merchants who mix them into a drug cocktail), and would be a world first. The contribution of such a test to the fight against drug-resistant strains of both HIV and TB would be huge, not to mention the verification and efficacy boost for patient drug compliance.

\section{A single test of a person living} with AIDS can show if they have remained compliant over the past year (there are increasing reports of $A R V$ users selling their drugs to merchants who mix them into a drug cocktail), and would be a world first. The contribution of such a test to the fight against drugresistant strains of both HIV and $T B$ would be huge, not to mention the verification and efficacy boost for patient drug compliance.

When it comes to FAS, Lasarow speaks passionately, arguing the case for philanthropic profit-making with ease and eloquence. Not only does he want to use his tests to monitor pregnant mothers (the Medical Research Council (MRC) is busy testing 600 pregnant women in pilot research), but he wants to analyse the infant's meconium for indicators of FAS within the first week and thus enable rapid intervention within a fortnight.

\section{Homeboy's patriotic goals}

His current goal is to 'exit myself out of my UK company and take the extra funds I generate there to start working heavily in South Africa. This is not just a pipe dream or solo entrepreneurial objective. He's been heavily involved in political projects, partnering with the ANC and sponsoring that party's initiatives to repatriate skills to South Africa for several years. Lasarow is a pivotal member of the Progressive Business Forum in London and a regular keynote speaker at the Homecoming Project and the South African Business Club. Last year he won the inaugural SA Business Award in London.

He explains his approach thus: 'About three years ago I was at the pre-manifesto launch of Jacob Zuma in Bloemfontein. Everyone was singing struggle songs and the hair stood up on the back of my neck - I realised how lucky I was to watch the emergence of a democracy. That's when I saw the opportunity to catch the vote of South Africans abroad. I can speak to those who "ran away" about my experience as an independent entrepreneur.' Lasarow speaks proudly of a new ANC branch forming in London which he believes will have the 'highest percentage of minority group members anywhere'.

In February this year he opened a R12 million laboratory in Manchester that will provide world-class hair substance abuse testing and begin research into a hair test for ARV compliance. He's confident this will soon result in protocols that can be tested in the field locally. Lasarow said patients with AIDS were being 'mugged and robbed of their ARVs', which were smoked in a dagga cocktail, while other desperately poor patients were selling their pills to make money.

\section{Commercialising science to uplift populations}

The young entrepreneur has no formal qualifications but partners with top scientists, using his razor-sharp intellect to translate research into marketable technology. He's no stranger to failure, having made and lost a fortune in DNA testing when one of his 
shareholders, the blind British former social security minister, David Blunkett, became embroiled in a paternity scandal six years ago. ${ }^{1}$ Fleet Street newspapers had a rollicking time when they found out that Blunkett, who wrote the foreword to Lasarow's book, Who is Really Who? - A Comprehensive Guide to Paternity Testing, had also failed to disclose to parliament his shares in Lasarow's company. Blunkett's name has since entered popular culture in Britain, being thriceportrayed in dramatic or musical form, one such being 'Who's the Daddy?' The Sheffield Blind Institute in his home town even began a local club night, called 'The Electric Blunkett'.

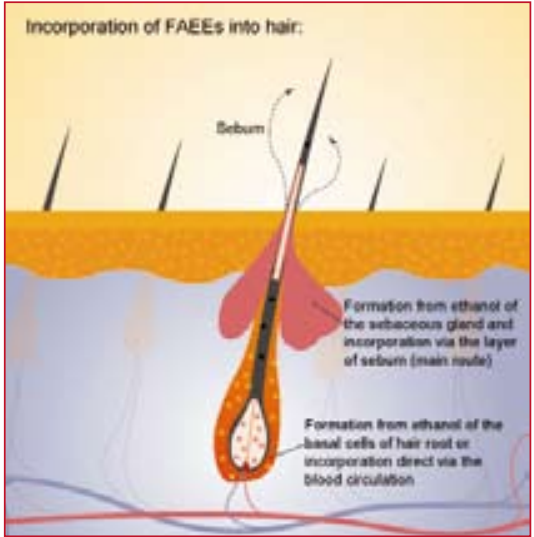

As the hair grows, it absorbs special marker called fatty acid ethyl esters (FAEEs) and ethyl glucuronide (EtG) into its structure. While FAEE gets into the hair mainly by diffusion from an external sebum layer, EtG markers are formed almost exclusively in the liver and then deposited into hair mainly from sweat. The more markers there are, the more alcohol has been consumed.

Blunkett and Lasarow's paternity testing business partnership was no mere coincidence. Both fought and won battles to prove their paternity to children born of former partners, an experience so traumatic for Lasarow that he vowed to come up with a less painful bio-scientific and simpler manner of verification - and thus made his first brief-lived fortune.
Lasarow liquidated his company, DNA BioScience, then picked himself up, working with a handful of loyal colleagues, 'from a room no bigger than a broom cupboard' at the Old Bailey in London, where he began exploring hard drug testing. The UK Office of Science and Technology soon pronounced hair drug testing as the gold standard because of its long window of evidence - and the courts followed suit. Child custody cases were at first Lasarow's mainstay because of the UK courts' reluctance to place children in mainstream childcare facilities (with all their negative and often criminal outcomes), making permanent caregivers (or parents) the favoured option. This put parental/ caregiver suitability on top of the checklist and placed Lasarow's drug hair testing centre stage, ahead of liver function and blood test (complementing but not replacing them).

\section{Shown a snapshot of South} Africa's gruesome alcohol-related statistics, Lasarow said the notorious backlogs in the country's blood testing laboratories (read National Health Laboratory Services), needed urgent addressing to restore law enforcement credibility.

\section{Restore law enforcement credibility}

Shown a snapshot of South Africa's gruesome alcohol-related statistics, Lasarow said the notorious backlogs in the country's blood testing laboratories (read National Health Laboratory Services), needed urgent addressing to restore law enforcement credibility.

'I'd try and work with legislation to allow third partylabs to do these testsand implement a fast and efficient lab to shorten the whole customer journey', he said. Another wide open pasture of entrepreneurial endeavour locally would be drug and alcohol hair testing pre-driver-licensing and improved regular testing of long-distance drivers and

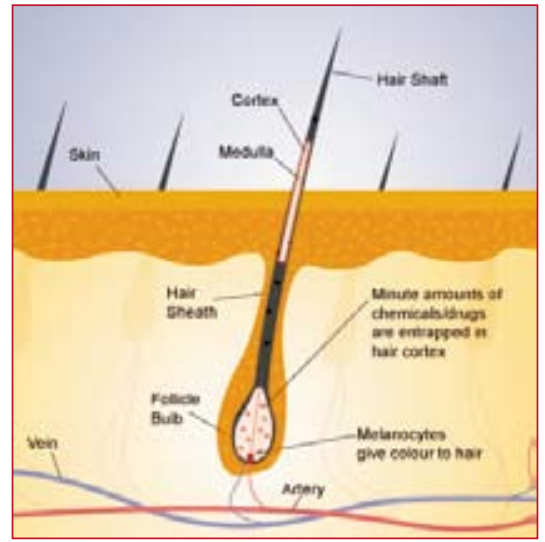

Using a small sample of hair cut from the scalp, hair analysis evaluates the number of drug metabolites embedded inside the hair shaft. When compared with more traditional forms of testing (i.e. urine testing), hair samples can detect a longer period of drug use. With urine, most drugs are undetectable if urinalysis is carried out more than 2 - 3 days after use, with the exception of cannabis, which may be detected for slightly longer periods of time.

airline pilots. 'Basically policy and legislation need to be tightened up to catch up so we can start dealing with some of these social ills effectively', Lasarow concludes.

A Trimega poster to the Society of Hair Testing bi-annual conference resulted in consensus that the combined marker used by Lasarow's company is the 'marker of choice'. When blood and other tests are correlated with these results, most courts are able to rule beyond reasonable doubt.

Asked what his formula for success is, Lasarow says most people believe there are limitations to entrepreneurial success. 'But you can upskill yourself on certain topics. I've been close to this for a long time and understand the technology. I know the markets exist and I've got a lead on it. I want to bring those skills back to South Africa.'

\section{Chris Bateman}

1. Bateman C. Blind former British Home Secretary backs new call phone initiative. S Afr Med J 2008;98(7):506-508. 